\title{
AC 2011-497: ENGINEERING STUDENT SUCCESS: AN INTERVENTION COURSE
}

\author{
Dianne Raubenheimer, North Carolina State University
}

Dr. C. Dianne Raubenheimer is Director of Assessment in the College or Engineering and Adjunct Assistant Professor in the Department of Adult and Higher Education at NC State University. Within the College of Engineering she serves as the coordinator of ABET and other accreditation processes, acts as a resource/consultant to faculty in the different programs, develops and implements assessment plans, and serves as the primary educational assessment/data analyst adviser on the Dean's staff. A particular interest is in helping faculty to develop and implement classroom-based assessment and action research plans to establish the effectiveness of instruction and to use the data to improve teaching and student learning. She is currently working with several engineering faculty assessing the impact of in-class use of technology on teaching and student learning. Dianne has also worked as an education consultant for a number of organizations conducting program evaluations and is currently serving as external evaluator on several grants. Her research interests focus on faculty development, action research, the role of technology in teaching and learning, and assessment in higher education.

\section{Jerome P. Lavelle, North Carolina State University}

Jerome P. Lavelle, Ph.D. is Associate Dean of Academic Affairs in the College of Engineering at North Carolina State University.

\section{Monica Terrell Leach, NC State University \\ Steven L. White, NC State University}

Steven White is a Data Research Analyst in the Enrollment Management and Services office at North Carolina State University. He received a Bachelor of Science degree in Business Administration (2005) and in Information Systems and Operations Management (2008) at The University of North Carolina at Greensboro.

\section{Philip Albert Moses, North Carolina State University}

Moses is completing his 16th year at North Carolina State University in the Academic Support Program for Student Athletes (ASPSA). He has been recognized by his peers as a national leader in the field of athletic academic advising. He has had the privilege of serving as President of the National Association of Academic Advisors for Athletics (N4A). The Academic Support Program for Student Athletes at NC State has been recognized by the National Academic Advising Association (NACADA) as an exemplary program.

Prior to coming to NC State in 2005 Moses worked in the academic support programs at Texas A\& M University and Arizona State University. He has also been employed as a reading specialist, principal, youth program counselor and as a private tutor for the children of then Governor Hugh Carey in New York.

Moses received his masters in reading from SUNY Albany, his bachelors in physical education from SUNY Cortland and his associates in liberal arts from Paul Smith's College. 


\title{
Engineering Student Success: A First-Year Intervention Course
}

\begin{abstract}
This paper describes a collaborative effort of campus partners at a large public university to pilot test a new course aimed at underperforming second-semester engineering students. Through this effort, we develop and test a model structure and curriculum that can be used for the entire campus community related to improving the academic success of underperforming students. The course, entitled E298 Engineering Student Success, was offered for the first time in spring 2009 and involved collaborative teaching teams from the College of Engineering, the Division of Enrollment Management and Services (EMAS), and the Academic Support Program for Student Athletes (ASPSA) in the Division of Undergraduate Academic Programs (DUAP). The curriculum for the course focused on developing learning outcomes and competencies related to: academic performance; time management and organizational skills; stress management; decision-making, and academic and test taking skills.
\end{abstract}

\section{Introduction}

In an effort to improve retention and persistence rates at the university, the Division of Enrollment Management and Services (EMAS), Academic Support Program for Student Athletes (ASPSA) and the College of Engineering embarked on an exciting project. The goal was to develop and pilot test a second-semester intervention course for students whose first semester grades placed them on academic warning status at the university. Previously, no such course existed.

The literature on student retention is very rich, and research shows that the issue involves a complex ${ }^{1}$ and convergent ${ }^{2}$ set of factors. Retention at colleges and universities is important for schools as well as society ${ }^{3}$. Indeed, it is more cost effective to retain current students than to recruit new ones ${ }^{4}$. The retention of students continues to be a concern for college administrators in higher education institutions. Some of the literature on retention suggests that it is critical for retention programs to teach study and learning skills in the form of programs. A review of the retention literature also shows that when colleges address the issue programmatically, they have a positive effect on students' persistence. A major objective of retention programs is to boost students' academic skills while also helping to develop important social networks ${ }^{5}$. To further explain, Tinto identifies three principles for institutions to consider when implementing effective retention programs ${ }^{6}$. Effective retention programs are committed to:

(1) The students they serve. They put student welfare ahead of other institutional goals.

(2) The education of all, not some, of their students.

(3) The development of supportive social and educational communities in which all students are integrated as competent members.

The data also suggests that increasing numbers of students are choosing to leave college or the university before completing their degree. Tinto states that of "nearly 2.4 million students who in 1994 entered higher education for the first time, over 1.5 million will leave their first institution without receiving a degree" ${ }^{6}$. Therefore, the number of students leaving their higher education institution exceeds the number of students who decide to remain on campus. This retention issue has a direct impact on the financial stability and the academic credibility of the institution. For 
more than four decades researchers and practitioners have created an extensive body of literature exploring retention. But while the field possesses infinite theoretical schemas, Tinto ${ }^{7}$ suggests that complex theoretical principles are unbeneficial for practitioners who have to translate research into effective practice.

In previous years retention was simply viewed as a reflection of a student's lack of individual attributes, skills, and motivation. With this view students were expected to assimilate and "rise to the task" at their institutions. This view prohibited institutions from recognizing their intricate role in providing a successful platform for students. Since then our institutions and theorists have begun to realize that retaining students is contingent upon the institution as well as the student. We currently see institutions creating transition programs, academic support and other variations to ensure students matriculate successfully. But with the increase in programming the national rate of student persistence and graduation rate has showed slight changes over the past decade $^{8}$.

Regarding engineering students specifically, Felder ${ }^{9}$ asserts, a common misunderstanding in the retention of this population is that academic failure results from their inability to cope with the "rigors of the discipline." In fact, studies demonstrate no assignable academic differences between engineering students who persist and those who do not ${ }^{10,11,12}$. Felder ${ }^{9}$ explains the persistence differences involve "a complex set of factors including students' attitudes toward engineering, their self-confidence levels, and the quality of their interactions with instructors and peers ${ }^{10,13,14,15}$ along with their aptitude for engineering." Caison ${ }^{16}$ concludes that in order to maximize the effects of academic interventions, colleges and universities should match proposed strategies with the target population. The E298 course, curriculum and structure was designed with these effects this in mind.

\section{Course details}

The objective of the course is to assist underperforming students in understanding their particular academic challenges, and to set in place appropriate strategies to improve that performance and their overall personal success in college. To this end, the course provides an overview of college success strategies and university resources available to students. Topics in the course include self-assessment, motivation, goal-setting, study skills, learning styles, time management, organizational skills, stress management, decision making, and discovery of campus resources. Teaching methods and interventions from On Course: Strategies for Success in College and in Life (5th ed.) by Skip Downing ${ }^{17}$ were used to develop some of the curriculum, as well as successful strategies from faculty members who have taught similar courses, including models from the Academic Support Programs for Student Athletes.

During the development of the course, multiple retention and advising experts from across campus were used to develop the best possible course in terms of content and delivery. Within each faculty team different people lead specific classes from their expert area. Thus, students benefitted from having a variety of teaching styles and personalities to draw on. 
The anticipated student learning outcomes for the course are listed below:

- First year undergraduate students will identify strategies to improve their academic standing.

- Students will understand the areas of improvement that are particularly challenging their academic performance.

- Students will identify success strategies to utilize in all academic courses.

- Students will become aware of University campus resources.

Topics covered during the course include, (a) Self-assessment and Monitoring Tools, (b) Time Management and Organizational Skills, (c) Stress Management, (d) Decision-making, (e) Academic Skills and Strategies, (f) Computer Skills, and, (g) Locating and Accessing Campus Resources.

The course requires weekly attendance and participation, and includes both individual and group assignments. Student journaling is a central theme in this course as a mechanism to promote proactive thinking as well as reflection. Aside from daily assignments students are required to have two detailed academic coaching sessions with faculty members. These sessions are used to obtain feedback on class performance, direction on stated goals, and review of each student's personal plan for success. All assignments are correlated with developing study skills, time management, college success strategies, and knowledge about on-campus resources. Students receive a letter grade for this one semester credit-hour course. Students are assessed through a range of tasks as shown in Table 1 below:

Table 1: Weekly assignments and point allocation

\begin{tabular}{|l|c|c|c|}
\hline Assignment & Point Value & Points Earned & Due Date \\
\hline Attendance & 150 & & ALL \\
\hline Academic Success Questionnaire & 30 & & January 11 \\
\hline Academic Weekly Plan & 30 & & January 18 \\
\hline Academic Update Report & 60 & & January 18 \\
\hline Goal Setting Worksheet & 30 & & January 25 \\
\hline Individual Conference \#1 & 50 & & Completed by February \\
\hline Self Assessment \& Personal Inventory Worksheet & 30 & & February 1 \\
\hline Journal \#1: Learning Styles Reflection & 60 & & February 8 \\
\hline Journal \#2: Stress Management Reflection & 60 & & February 15 \\
\hline Updated Academic Update Report & 30 & & February 15 \\
\hline Course Grades \& GPA Calculation Worksheet & 30 & & February 22 \\
\hline Course Selection Worksheet & 30 & & March 1 \\
\hline Journal \#3: Letter to Next Year's Freshmen & 60 & & March 1 \\
\hline Life Map & 30 & & March 15 \\
\hline Journal \#4: Resume & 60 & & March 15 \\
\hline Journal \#5: Case Studies Reflection 22 \\
\hline Individual Conference \#2 & 60 & & Completed by April 5 \\
\hline Final: Video Presentation & 50 & & April 19 \\
\hline Total Points Possible & 150 & & \\
\hline
\end{tabular}


Participation counts for $15 \%$ of the grade, reflective journals for $30 \%$, individual conferences for $10 \%$, various assignments for $30 \%$ and a final video for $15 \%$. The video production is a group project in which students integrate the topics covered during the semester. The course grading scale is typical of other first year courses with $A=90-100 \%, B=80-89 \%, C=70-79 \%, D=60$ $69 \%$ and $\mathrm{F}=59 \%$ or less.

Three sections of the class were held in the spring semesters of 2009 and 2010, and the course is offered again in 2011. A team of personnel from the collaborating campus units made up the instructional team - with three/four instructors on each team. This resulted in a student to facilitator ratio of between 4-8 to 1 .

In year two, a new university suspension policy was put in place, with students with below a 1.0 at the university being automatically suspended, whereas in year 2009 these students had been included in the participating group. Between year 1 and 2 the course was refined to meet the needs of the students. The second year was more formalized in terms of schedule, assignments and requirements of the students, specifically to address their needs more successfully.

\section{Target Audience:}

The target audience for the initial audience of the course was all first-time, full-time, first-year undergraduate engineering students on academic warning at the completion of the fall 2008 semester. This group involved students whose total GPA was less than 2.0 (on a 4.0 scale). For the entering 2008 cohort, there were 184 students eligible for enrollment in the course-and 169 for the entering 2009 cohort. In spring 2009, 68 students participated in the course, and 31 in spring 2010. Students from the eligible population were not required to take the course in these years. Rather, it was an elective choice they were encouraged to take. Table 1 shows the demographics of the participants and eligible non-participants.

Table 1: Demographics of students who were eligible for participating in E298

\begin{tabular}{|c|c|c|c|c|c|c|c|c|}
\hline \multirow{2}{*}{\multicolumn{2}{|c|}{$\begin{array}{c}\text { Entering } 2008 \\
\text { cohort }\end{array}$}} & \multicolumn{6}{|c|}{ Ethnicity } & \multirow[t]{3}{*}{$\mathbf{N}$} \\
\hline & & \multirow[t]{2}{*}{ White } & \multirow{2}{*}{$\begin{array}{c}\text { African } \\
\text { American } \\
\end{array}$} & \multirow{2}{*}{$\begin{array}{c}\text { Native } \\
\text { American } \\
\end{array}$} & \multirow[t]{2}{*}{ Asian } & \multirow[t]{2}{*}{ Hispanic } & \multirow[t]{2}{*}{ Other } & \\
\hline Group* & Gender & & & & & & & \\
\hline \multirow[t]{2}{*}{ E298 } & $\mathbf{F}$ & 6 & 3 & . & . & . & . & 9 \\
\hline & $\mathbf{M}$ & 49 & 5 & 1 & 1 & 2 & 1 & 59 \\
\hline \multirow{2}{*}{$\begin{array}{l}\text { Non- } \\
\text { E298 }\end{array}$} & $\mathbf{F}$ & 11 & 4 & . & . & 1 & . & 16 \\
\hline & $\mathbf{M}$ & 77 & 12 & . & 6 & 3 & 2 & 100 \\
\hline
\end{tabular}




\begin{tabular}{|c|c|c|c|c|c|c|c|c|}
\hline \multirow{2}{*}{\multicolumn{2}{|c|}{$\begin{array}{c}\text { Entering } 2009 \\
\text { cohort }\end{array}$}} & \multicolumn{6}{|c|}{ Ethnicity } & \multirow[t]{3}{*}{$\mathbf{N}$} \\
\hline & & \multirow[t]{2}{*}{ White } & \multirow{2}{*}{$\begin{array}{c}\text { African } \\
\text { American }\end{array}$} & \multirow{2}{*}{$\begin{array}{c}\text { Native } \\
\text { American } \\
\end{array}$} & \multirow[t]{2}{*}{ Asian } & \multirow{2}{*}{ Hispanic } & \multirow{2}{*}{ Other } & \\
\hline Group* & Gender & & & & & & & \\
\hline \multirow[t]{2}{*}{ E298 } & $\mathbf{F}$ & 2 & 1 & & & 2 & 1 & 6 \\
\hline & $\mathbf{M}$ & 21 & 2 & & & 2 & & 25 \\
\hline \multirow{2}{*}{$\begin{array}{l}\text { Non- } \\
\text { E298 }\end{array}$} & $\mathbf{F}$ & 12 & 3 & 1 & 2 & & 3 & 21 \\
\hline & M & 86 & 8 & & 11 & 3 & 9 & 117 \\
\hline
\end{tabular}

* E298 are students who elected the course, Non-298 were eligible but did not enroll.

High school GPA and SAT scores for students in three comparison groups are given on Table 2 below.

Table 2a: HSGPA and SAT scores for three comparison groups in the 2008 cohort

\begin{tabular}{|c|r|r|r|r|r|r|r|}
\hline $\begin{array}{c}\text { Entering 2008 } \\
\text { cohort }\end{array}$ & \multicolumn{2}{|c|}{ HSGPA*** } & \multicolumn{2}{c|}{ SATM } & \multicolumn{2}{c|}{ SATV } & $\begin{array}{c}\text { N of } \\
\text { students } \\
\text { Gith data }\end{array}$ \\
\hline Group & Mean & StdDev & Mean & StdDev & Mean & StdDev & 68 \\
\hline Non-E298* & 4.11 & 0.26 & 633 & 68.7 & 586.6 & 66.1 & 85 \\
\hline $\begin{array}{c}\text { Other } \\
\text { comparison } \\
\text { group } * *\end{array}$ & 4.17 & 0.26 & 637 & 65.6 & 582 & 65.8 & 78 \\
\hline
\end{tabular}

* E298 are students who elected the course, Non-298 were eligible but did not enroll

** Students in this group were not invited to participate in E298, but had only a nominally better GPA in their first semester. They obtained a total GPA between 2.0 and 2.3 in fall 2008.

*** This is on a 5.0 scale that is weighted for advanced placement (AP) courses. 
Table 2b: HSGPA and SAT scores for three comparison groups in the 2009 cohort

\begin{tabular}{|c|r|r|r|r|r|r|r|}
\hline $\begin{array}{c}\text { Entering 2009 } \\
\text { cohort }\end{array}$ & \multicolumn{2}{|c|}{ HSGPA*** } & \multicolumn{2}{|c|}{ SATM } & \multicolumn{2}{c|}{ SATV } & $\begin{array}{c}\text { N of } \\
\text { students } \\
\text { with data }\end{array}$ \\
\hline Group & Mean & StdDev & Mean & StdDev & Mean & StdDev & 31 \\
\hline Non-E298* & 4.15 & 0.22 & 618 & 52.4 & 576 & 60.1 & 117 \\
\hline $\begin{array}{c}\text { Other } \\
\text { comparison } \\
\text { group } * *\end{array}$ & 4.14 & 0.24 & 637 & 62.2 & 577 & 71.8 & 71 \\
\hline
\end{tabular}

* E298 are students who elected the course, Non-298 were eligible but did not enroll

** Students in this group were not invited to participate in E298, but had only a nominally better GPA in their first semester. They obtained a total GPA between 2.0 and 2.3 in fall 2009.

*** This is on a 5.0 scale that is weighted for advanced placement (AP) courses.

\section{Assessment of the Course}

Several methods were employed to evaluate the course and its effect on student performance and success, included were (1) detailed analysis of grades obtained in E298, (2) cumulative GPAs of E298 students and two comparison groups, (3) pre-post semester student attitude survey of students participating in E298, (4) a survey of students' views one to three semesters after completing the course.

\section{(1) Analysis of the E298 Grades:}

Tables 3a and 3b show the grades of students who were enrolled in the E298 course in spring 2009 and 2010. The majority of students (75\%) scored a C grade or higher in the course.

Table 3a: Overall E298 grades and end of semester grades for 2008 cohort

\begin{tabular}{|c|c|c|c|}
\hline 2008 Cohort & Fall 08 Total GPA & Spring 09 Total GPA & \\
\hline Grade in E298 & Mean & Mean & N \\
\hline A+ & 1.55 & 2.48 & 12 \\
\hline A & 1.46 & 2.20 & 24 \\
\hline A- & 1.38 & 1.86 & 3 \\
\hline B+ & 1.34 & 2.13 & 2 \\
\hline B & 1.62 & 2.29 & 5 \\
\hline B- & 1.75 & 2.09 & 3 \\
\hline D & 1.17 & 0.86 & 2 \\
\hline F & 1.86 & 1.31 & 1 \\
\hline W* & 1.04 & 0.93 & 13 \\
\hline Mean & 0.98 & 1.03 & 3 \\
\hline
\end{tabular}

* Students who withdraw from the course during the semester. 
Table 3b: Overall E298 grades and end of semester grades for 2009 cohort

\begin{tabular}{|c|c|c|c|}
\hline 2009 Cohort & Fall 09 Total GPA & Spring 10 Total GPA & \\
\hline Grade in E298 & Mean & Mean & N \\
\hline A+ & 1.70 & 2.54 & 8 \\
\hline A & 1.52 & 2.32 & 14 \\
\hline A- & 1.28 & 1.82 & 4 \\
\hline B+ & 1.52 & 2.25 & 1 \\
\hline B & 1.51 & 1.82 & 1 \\
\hline C+ & 1.03 & 1.73 & 1 \\
\hline F & 1.51 & 1.87 & 1 \\
\hline Mean & 1.86 & 1.12 & 1 \\
\hline
\end{tabular}

To test the hypothesis that there were no differences between four different groups, a one way ANOVA was conducted on total end-of-semester grades (i.e., cumulative GPAs). The four groups were (a) all E298 students, (b) E298 students making As and Bs, (c) students who chose not to participate in E298, and (d) a comparison group of students not eligible for E298 (those who obtained between a 2.0 and 2.3 GPA at the end of the first fall semester). This analysis does not include course repeat grades, that is, the analysis used the initial grades and associated GPAs obtained by students, before any course repeat grades were factored in. Tables $4 \mathrm{a}$ and $4 \mathrm{~b}$ show the results for the 2008 and 2009 cohorts respectively.

Table 4a: Total end of semester grades for 2008 cohort

\begin{tabular}{|l|c|c|c|c|c|c|}
\hline \multicolumn{1}{|c|}{2008 cohort } & \multicolumn{2}{|c|}{$\begin{array}{c}\text { Fall 2008 total } \\
\text { GPA }\end{array}$} & \multicolumn{2}{c|}{$\begin{array}{c}\text { Spring 2009 total } \\
\text { GPA }\end{array}$} & Significance \\
\hline & Mean & Std.Dev & Mean & Std.Dev & $\mathrm{N}$ & \\
\hline Group & & & & & & \\
\hline All E298 & $1.39^{\mathrm{a}}$ & 0.46 & $1.89^{\mathrm{d}}$ & 0.82 & 68 & $p<0.001$ \\
\hline E298 with As and Bs & $1.50^{\mathrm{b}}$ & 0.37 & $2.25^{\mathrm{e}}$ & 0.61 & 49 & $p<0.001$ \\
\hline Non-E298 & $1.47^{\mathrm{c}}$ & 0.53 & $1.90^{\mathrm{ef}}$ & 0.61 & 116 & $p<0.001$ \\
\hline $\begin{array}{l}\text { Other comparison } \\
\text { group * }\end{array}$ & $2.18^{\text {ab c }}$ & 0.17 & $2.26^{\mathrm{df}}$ & 0.57 & 78 & $p=0.232$ \\
\hline
\end{tabular}

* Students in this group were not invited to participate in E298, but had only a nominally better GPA in their first semester. They obtained a total GPA between 2.0 and 2.3 in fall 2008.

abcde indicate statistically significant differences between groups. 
Table 4b: Total end of semester grades for 2009 cohort

\begin{tabular}{|l|c|c|c|c|c|c|}
\hline 2009 cohort & \multicolumn{2}{|c|}{$\begin{array}{c}\text { Fall 2009 total } \\
\text { GPA }\end{array}$} & \multicolumn{2}{c|}{$\begin{array}{c}\text { Spring 2010 } \\
\text { total } \\
\text { GPA }\end{array}$} & $\begin{array}{c}\text { GPA } \\
\text { Improvement }\end{array}$ \\
\hline & Mean & Std.Dev & Mean & Std.Dev & $\mathrm{N}$ & \\
\hline Group & & & & & & \\
\hline All E298 & $1.53^{\mathrm{a}}$ & 0.33 & $2.22^{\mathrm{d}}$ & 0.53 & 31 & $p<0.001$ \\
\hline E298 with As and Bs & $1.52^{\mathrm{b}}$ & 0.33 & $2.27^{\mathrm{e}}$ & 0.50 & 29 & $p<0.001$ \\
\hline Non-E298 & $1.53^{\mathrm{c}}$ & 0.42 & $1.88^{\mathrm{def}}$ & 0.66 & 138 & $p<0.001$ \\
\hline $\begin{array}{l}\text { Other comparison } \\
\text { group }^{*}\end{array}$ & $2.15^{\mathrm{abc}}$ & 0.09 & $2.24^{\mathrm{f}}$ & 0.52 & 87 & $p=0.189$ \\
\hline
\end{tabular}

* Students in this group were not invited to participate in E298, but had only a nominally better GPA in their first semester. They obtained a total GPA between 2.0 and 2.3 in fall 2009.

a b c d e f indicate statistically significant differences between groups.

\section{Grades Assessment: Within group comparisons}

- The results show for both years that, overall, students who took E298, as well as the group who were eligible but did not take the class, significantly increased their spring GPAs in comparison to the fall GPAs. So, both groups were able to increase their total GPAs at the end of the second semester, which is generally perceived to be more difficult than the first semester. One explanation for this is that the dean's letter and notification to parents of failing grade in fall, in itself, prompted students to action. However, further investigation, such as through interviews with students, is needed to test this hypothesis.

- Students who achieved As and Bs in E298, significantly increased total spring GPA over total fall GPA, making average gains of .75 GPA points. For the fall 2009 cohort, only 2 (6.5\%) of students earned a C grade or lower for E298, as compared to 16 (23.4\%) for the previous cohort. A possible explanation is that students who were motivated to improve their grades took the course, did well in the course and improved their cumulative GPA. Again, further investigation is needed to test this hypothesis.

- The comparison group of students who received fall GPA of between 2.0 and 2.3 did not significantly increase their total GPA by the end of spring, for both years of analysis.

\section{Grades Assessment: Between group comparisons}

- There was no significant difference between the total spring GPAs of the group of students who took E298 in spring 2009 and those who were eligible, but chose not to take the course. However, when results were separated out, there was a significant difference between the group of students who made As and Bs in E298, and the students who chose not to take E298. In other words, the student making As and Bs in E298 significantly outperformed those who chose not to take E298.

- For the students who took E298 in the spring 2010 there was a significant increase in the end of spring semester grades as compared to students who did not take E298 but were eligible to do so. The difference is even greater when comparing only those who scored As and Bs in E298 to the students who were eligible but who did not take the course. 
- A further comparison of students in both years who earned an A or B in E298 to students with a fall GPA between 2.0 and 2.3, showed that the spring GPAs were comparable in both years. That is, there was no significant difference in grades between the groups at the end of the spring semester, despite there being a significant difference in GPAs between the two groups at the end of the fall semester. Those who did well in the course increased their cumulative GPA to the level of students in the comparison group.

- Student who chose not to take E298 in had significantly lower end of spring GPAs as compared to the other comparison group, for both years.

- The above results indicate that students who were serious about E298 were very successful in increasing their overall spring grades.

\section{(2) Student Attitudes Survey:}

Ting $^{18}$ showed that there are several non-cognitive factors that impact the success of first-year engineering students. Key predictors of success were (a) SAT total and SAT math scores, (b) leadership experience, (c) long-term goals (d) positive self-concept. To assess E298, a 72 item survey was developed that included selected constructs and associated questions from Ting's non-cognitive survey ${ }^{19}$, selected constructs from the Manual for the Patterns of Adaptive Learning Scales (PALS) ${ }^{20}$, and from the Perceived Stress Scale survey ${ }^{21}$. Constructs selected from these different survey instruments included (a) self-appraisal system, (b) long-range goals, (c) motivation, (d) study method and effectiveness, (e) expectation of involvement with faculty, (f) emotional intelligence, (g) personal achievement goal orientation, (h) academic efficacy, (i) approaches to studying, and $(\mathrm{k})$ tolerance of stress.

The survey was administered to students at the beginning of the semester and again at the end of semester. Each self-rating was given a score ( 5 = strongly agree, $4=$ agree, $3=$ neutral, $2=$ disagree, 1 = strongly disagree) and the pre- and post-test means for each item were compared using a paired sample t-test. Only students completing both surveys were included in the analysis. For the purposes of this paper, only the items showing statistically significant differences are included in Table 5a-d. Results that are presented include individual questions as well as aggregate constructs that showed significant differences between the pre- and postsurveys. 


\section{Section A: Non-cognitive variables}

Table 5a: Survey items showing statistically significant differences between pre- and post-survey responses for non cognitive variables

\begin{tabular}{|l|r|r|r|}
\hline $\begin{array}{l}\text { Section A: Non-cognitive variables } \\
\text { Please rate these statements as they relate to } \\
\text { yourself. (5 = strongly agree, } \mathbf{4}=\mathbf{a g r e e , ~} \mathbf{3}= \\
\text { neutral, 2 = disagree, 1 = strongly disagree). }\end{array}$ & pre-test & post-test & $\boldsymbol{P}$ value \\
\hline 2009 Results & 4.04 & 4.32 & 0.01 \\
\hline $\begin{array}{l}\text { 2. I know the areas where I am weak and I try to } \\
\text { improve on them }\end{array}$ & 3.50 & 3.84 & 0.05 \\
\hline 7. I usually study in the library or a favorite place. & 3.34 & 3.61 & 0.03 \\
\hline $\begin{array}{l}\text { 17. If tutoring is made available on campus at no } \\
\text { cost, I will attend regularly. }\end{array}$ & 4.03 & 4.26 & 0.05 \\
\hline 21. I like to study a variety of subjects. & 2.54 & 2.77 & 0.05 \\
\hline $\begin{array}{l}\text { 23. I tend to skip classes when they are boring for me } \\
\text { or when I am not in a good mood. }\end{array}$ & 2.92 & 3.22 & 0.03 \\
\hline 29. I believe that my studying method is effective. & $\mathbf{1 5 . 9 7}$ & $\mathbf{1 6 . 5 9}$ & $\mathbf{0 . 0 3}$ \\
\hline Positive Self-Appraisal System (4 questions) & & & \\
\hline
\end{tabular}

\begin{tabular}{|l|r|r|r|}
\hline $\begin{array}{l}\text { Section A: Non-cognitive variables } \\
\text { Please rate these statements as they relate to } \\
\text { yourself. (5 = strongly agree, } \mathbf{4}=\text { agree, } \mathbf{3}=\end{array}$ & pre-test \\
neutral, 2 = disagree, 1 = strongly disagree). & post-test & P value \\
\hline 2010 Results & 3.52 & 3.96 & 0.02 \\
\hline 10. I usually mark important dates on my calendar. & 3.04 & 2.52 & 0.004 \\
\hline $\begin{array}{l}\text { 11. I don't expect to get to know faculty personally } \\
\text { during my first year. }\end{array}$ & 3.29 & 3.83 & 0.02 \\
\hline $\begin{array}{l}\text { 12. I have talked about my career goals with someone } \\
\text { who works in that career. }\end{array}$ & 3.20 & 3.68 & 0.04 \\
\hline $\begin{array}{l}\text { 18. I know what I want to be doing 10 years from } \\
\text { now. }\end{array}$ & 3.44 & 3.96 & 0.01 \\
\hline 19. I often make lists of things to do. & 2.84 & 3.36 & 0.03 \\
\hline 29. I believe that my studying method is effective. & $\mathbf{2 0 . 2 2}$ & $\mathbf{2 2 . 6 8}$ & $\mathbf{0 . 0 0 0}$ \\
\hline Long Range Goals (6 questions) & $\mathbf{1 9 . 2 4}$ & $\mathbf{2 0 . 5 6}$ & $\mathbf{0 . 0 5}$ \\
\hline Study Methods and Effectiveness (6 questions) & $\mathbf{1 3 . 9 6}$ & $\mathbf{1 4 . 8 4}$ & $\mathbf{0 . 3 3}$ \\
\hline $\begin{array}{l}\text { Expectations of Involvement with Faculty (5 } \\
\text { questions) }\end{array}$ & & & \\
\hline
\end{tabular}

Questions 2 and 17 relate to the 'positive self appraisal' construct which significantly increased by the end of the 2009 spring semester, with students saying that they are better able to evaluate 
their abilities and more willing to seek outside assistance. Overall, this construct significantly increased for this group when all questions in the construct were considered.

Questions 7, 23 and 29 reflect the 'study method and effectiveness' construct. Ratings significantly increased in seeking a quiet place to study for the spring 2009 group and in their rating of the effectiveness of their study methods. However, the 2009 group were also more likely to skip classes that were boring to them, which is a reversal of study effectiveness. Thus, overall this construct did not show a significant change at the end of the semester when all questions relating to the construct were considered. Thus, the only overall construct that improved significantly for the spring 2009 group was their appraisal of their abilities.

For the spring 2010 group, there was a significant improvement at the end of the semester in selfrating on three constructs, namely 'long range goals', 'study methods and effectiveness' and 'expectations of involvement with faculty.' This group of students became more goal-oriented, learned how to study more effectively, and indicated that engagement with faculty could enhance their academic success.

The two student groups in each year had different constructs that changed by the end of the course, indicating that there were different profiles and non-cognitive variables associated with each group. Constructs for which there was no change in either group were 'motivation' and 'emotional intelligence.'

\section{Section B: Views about learning}

Questions in this section indicate students' attitudes to four constructs on the Patterns of Adaptive Learning Scales, with 5 questions on the survey for each construct. The constructs are:

(1) Mastery Goal Orientation, with the main purpose being to develop competence, mastery and understanding.

(2) Performance Approach Goal Orientation, with the main purpose to demonstrate ability of self to others.

(3) Avoidance Goal Orientation, with the main goal of avoiding demonstrating the incompetence of self.

(4) Academic Efficiency, referring to self-perceptions of competence to do the class work. 
Table 5b: Survey items showing statistically significant differences between pre- and post-survey responses for views about learning

\begin{tabular}{|c|c|c|c|}
\hline $\begin{array}{l}\text { Section B: Patterns of adaptive learning } \\
\text { Please rate yourself on the following statements. } \\
\text { ( } 5=\text { always or almost always true, } 4=\text { often true, } 3 \\
=\text { true half of the time, } 2=\text { sometimes true, } 1= \\
\text { seldom true) }\end{array}$ & pre-test & post-test & $P$ value \\
\hline \multicolumn{4}{|l|}{2009 Results } \\
\hline $\begin{array}{l}\text { 36. It is important to me that I don't look stupid in } \\
\text { class.(Avoidance Goal Orientation) }\end{array}$ & 3.92 & 3.46 & 0.02 \\
\hline $\begin{array}{l}\text { 39. One of my goals is to show others that I am good } \\
\text { at my coursework. (Academic Performance Goal } \\
\text { Orientation) }\end{array}$ & 3.81 & 3.11 & 0.000 \\
\hline Avoidance Goal Orientation (5 questions) & 16.21 & 14.69 & 0.02 \\
\hline Academic Performance Goal (5 questions) & 15.95 & 14.15 & 0.01 \\
\hline \multicolumn{4}{|l|}{2010 Results } \\
\hline $\begin{array}{l}\text { 37. I'm certain I can master the skills taught in my } \\
\text { courses. (Academic Efficiency) }\end{array}$ & 3.24 & 3.80 & 0.06 \\
\hline $\begin{array}{l}\text { 38. One of my goals is to learn as much as I can. } \\
\text { (Mastery Goal Orientation) }\end{array}$ & 2.88 & 3.76 & 0.005 \\
\hline $\begin{array}{l}\text { 46. It is important to me that I thoroughly understand } \\
\text { my coursework. (Mastery Goal Orientation) }\end{array}$ & 3.08 & 3.84 & 0.02 \\
\hline $\begin{array}{l}\text { 49. Even if the work is hard, I can learn it. (Academic } \\
\text { Efficiency) }\end{array}$ & 2.88 & 3.80 & 0.002 \\
\hline $\begin{array}{l}\text { 53. I can do even the hardest work in my courses if I } \\
\text { try. (Academic Efficiency) }\end{array}$ & 3.00 & 3.84 & 0.005 \\
\hline Mastery Goal Orientation (5 questions) & 15.84 & 18.80 & 0.003 \\
\hline Academic Efficiency (5 questions) & 15.64 & 18.60 & 0.004 \\
\hline
\end{tabular}

The spring 2009 students showed significant decreases in the Avoidance Goal Orientation and in the Performance Approach Goal Orientation categories, suggesting these students were initially concerned about being seen as weak students in class and felt it was important to demonstrate competence to others. However, these two goals were significantly lower by the end of the semester, indicating that they decided that it was not so important if people thought they were weak students. They may also have become more willing ask for help.

For the spring 2010 students, significantly higher ratings were seen for the Academic Efficiency and the Mastery Goal Orientation constructs. This suggests that these students gained confidence in their ability to master difficult work, to study more effectively and in their academic self-efficacy. 
Again, it is interesting that the groups from the two years had very different patterns of adaptive learning. The authors are planning to conduct regression analysis on these factors to establish if any of these non-cognitive variables are predictors of subsequent success (such as at the end of the second fall semester) as was found by Ting for engineering students generally ${ }^{16}$.

\section{Section C: Approach to studying}

There were no significant differences between pre- and post-course ratings of students' approaches to studying for the 2009 group, but there were several significant differences for the 2010 group.

Table 5c: Survey items showing statistically significant differences between pre- and post-survey responses for approach to studying

\begin{tabular}{|l|r|r|r|}
\hline $\begin{array}{l}\text { Section C: Approach to studying } \\
\text { Please rate each of the following statements as they } \\
\text { apply to you. (5 = always or almost always true, } \mathbf{4}= \\
\text { often true, } \mathbf{3}=\text { true half of the time, } \mathbf{2}=\text { sometimes } \\
\text { true, } \mathbf{1}=\text { seldom true) }\end{array}$ & pre-test & post-test & P value \\
\hline 2009 Results - no significant differences & 2.32 & 2.80 & 0.04 \\
\hline 2010 Results & 2.48 & 3.24 & 0.001 \\
\hline $\begin{array}{l}\text { 54. I tend to start working on homework and projects a } \\
\text { day or so before they are due. }\end{array}$ & 1.20 & 1.64 & 0.002 \\
\hline $\begin{array}{l}\text { 55. I make sure that I keep up with weekly readings, } \\
\text { assignments and other course work for all my courses. }\end{array}$ & 2.33 & 3.38 & 0.000 \\
\hline $\begin{array}{l}\text { 56. It is not necessary to attend all class sessions } \\
\text { because I can get notes from other students later. }\end{array}$ & 2.04 & 2.83 & 0.000 \\
\hline $\begin{array}{l}\text { 58. Even when I find course materials are dull and } \\
\text { uninteresting, I manage to keep working until I finish. }\end{array}$ & & & \\
\hline $\begin{array}{l}\text { 60. I allocate an amount of time to studying and when } \\
\text { that time is up I stop even if I have not finished what I } \\
\text { planned to cover. }\end{array}$ & & & \\
\hline
\end{tabular}

Two questions, namely, 'I make sure that I keep up with weekly readings, assignments and other course work for all my courses' and 'Even when I find course materials are dull and uninteresting, I manage to keep working until I finish' suggest that the students have developed positive study habits in these areas. However, the other three questions suggest that some maladaptive behaviors have increased. Namely, that (1) they tend to start working on homework and projects late, (2) that there is an increase in the belief that it is not necessary to attend all classes because notes can be obtained from other students, and (3) that they tend to give up doing work after a set time even if they have not finished what they had planned to cover. 


\section{Section D: Stress tolerance}

In this section, only one factor was found to be significantly different for the spring 2009 group, and none for the 2010 group. Question 67 indicates that the 2009 group had significantly greater confidence in solving personal problems between the beginning and the end of the semester.

Table 5d: Survey items showing statistically significant differences between pre- and post-survey responses for stress tolerance

\begin{tabular}{|l|r|r|r|}
\hline $\begin{array}{l}\text { Section D - Stress tolerance: } \\
\text { Please rate these statements as they relate to you } \\
\text { in the last month. (5 = very often, } \mathbf{4}=\text { often, } \mathbf{3}= \\
\text { sometimes, } \mathbf{2}=\text { rarely, } \mathbf{1}=\text { never })\end{array}$ & pre-test & post-test & $\boldsymbol{P}$ value \\
\hline 2009 Results & 3.72 & 4.00 & 0.032 \\
\hline $\begin{array}{l}\text { 67. In the last month, how often have you felt } \\
\text { confident about your ability to handle your personal } \\
\text { problems? }\end{array}$ & & \\
\hline 2010 Results - no significant differences & & \\
\hline
\end{tabular}

\section{(3) Analysis of Student Retention:}

Tables $6 \mathrm{a}, 6 \mathrm{~b}$ and $6 \mathrm{c}$ show the percentage of students in each of three groups returning to the university in fall 2009, a) students who took E 298, b) students who were eligible but did not take E 298, and c) students who were not eligible for E 298, with a fall 2008 GPA between 2.0 and 2.3. Data was captured on the fall 2009 census data, 10 days after the start of the semester.

Table 6a: Percentage of 2008 students returning in fall 2009

\begin{tabular}{|c|c|c|c|c|c|c|c|c|}
\hline \multirow[t]{2}{*}{2008 cohort } & \multicolumn{2}{|c|}{$\begin{array}{c}\text { All E298 } \\
\text { students returning } \\
\text { fall } 2009\end{array}$} & \multicolumn{2}{|c|}{$\begin{array}{l}\text { E298 students } \\
\text { who passed the } \\
\text { course returning } \\
\text { fall } 2009\end{array}$} & \multicolumn{2}{|c|}{$\begin{array}{l}\text { Non-E298 } \\
\text { students } \\
\text { returning fall } \\
2009\end{array}$} & \multicolumn{2}{|c|}{$\begin{array}{c}\text { Other } \\
\text { comparison } \\
\text { group returning } \\
\text { fall } 2009\end{array}$} \\
\hline & Pct $\mathbf{N}$ & $\mathbf{N}$ & Pct N & $\mathbf{N}$ & Pct $\mathbf{N}$ & $\mathbf{N}$ & Pct $\mathbf{N}$ & $\mathbf{N}$ \\
\hline Initial cohort $\mathbf{N}$ & & 68 & & 52 & & 116 & & 78 \\
\hline $\begin{array}{l}\text { Not returning to } \\
\text { University }\end{array}$ & $4.4 \%$ & 3 & $5.8 \%$ & 3 & $0.9 \%$ & 1 & $2.6 \%$ & 2 \\
\hline $\begin{array}{l}\text { Returning to } \\
\text { University }\end{array}$ & $66.2 \%$ & 45 & $75 \%$ & 39 & $75.0 \%$ & 87 & $92.3 \%$ & 72 \\
\hline $\begin{array}{l}\text { Not eligible to } \\
\text { return to } \\
\text { University } *\end{array}$ & $29.4 \%$ & 20 & 19.2 & 10 & $24.1 \%$ & 28 & $5.1 \%$ & 4 \\
\hline $\begin{array}{l}\text { Returning to } \\
\text { college other than } \\
\text { COE }\end{array}$ & $2.2 \%$ & $\begin{array}{c}\text { 1out of } \\
45\end{array}$ & $2.6 \%$ & $\begin{array}{c}\text { 1out of } \\
39\end{array}$ & $9.2 \%$ & $\begin{array}{l}8 \text { out } \\
\text { of } 77\end{array}$ & $4.2 \%$ & $\begin{array}{l}3 \text { out } \\
\text { of } 72\end{array}$ \\
\hline
\end{tabular}


Table 6b: Percentage of 2008 students returning in fall 2010

\begin{tabular}{|l|c|c|c|c|c|c|c|c|}
\hline 2008 cohort & \multicolumn{2}{|c|}{$\begin{array}{c}\text { All E298 } \\
\text { students returning } \\
\text { fall } 2010\end{array}$} & \multicolumn{2}{c|}{$\begin{array}{c}\text { E298 students } \\
\text { who passed the } \\
\text { course returning } \\
\text { fall } 2010\end{array}$} & \multicolumn{2}{c|}{$\begin{array}{c}\text { Non-E298 } \\
\text { students } \\
\text { returning fall } \\
2010\end{array}$} & \multicolumn{2}{c|}{$\begin{array}{c}\text { Other } \\
\text { comparison } \\
\text { group returning } \\
\text { fall } 2010\end{array}$} \\
\hline & Pct N & $\mathbf{N}$ & Pct N & $\mathbf{N}$ & Pct N & $\mathbf{N}$ & Pct N & N \\
\hline Initial cohort N & & 68 & & 52 & & 116 & & 78 \\
\hline $\begin{array}{l}\text { Not returning to } \\
\text { University }\end{array}$ & $13.2 \%$ & 9 & $9.6 \%$ & 5 & $6.0 \%$ & 7 & $19.2 \%$ & 15 \\
\hline $\begin{array}{l}\text { Returning to } \\
\text { University }\end{array}$ & $50.0 \%$ & 34 & $59.6 \%$ & 31 & $70.0 \%$ & 81 & $71.8 \%$ & 56 \\
\hline $\begin{array}{l}\text { Not eligible to } \\
\text { return to } \\
\text { University * }\end{array}$ & $36.8 \%$ & 25 & $30.8 \%$ & 16 & $24.0 \%$ & 28 & $9.0 \%$ & 7 \\
\hline $\begin{array}{l}\text { Returning to } \\
\text { college other than } \\
\text { COE }\end{array}$ & $47.1 \%$ & $\begin{array}{l}16 \text { out } \\
\text { of } 34\end{array}$ & $38.7 \%$ & 12 out & $38.3 \%$ & 31 out \\
of 81 & $44.6 \%$ & 25 out \\
of 56 \\
\hline
\end{tabular}

Table 6c: Percentage of 2009 students returning in fall 2010

\begin{tabular}{|c|c|c|c|c|c|c|c|c|}
\hline \multirow[t]{2}{*}{2009 cohort } & \multicolumn{2}{|c|}{$\begin{array}{c}\text { All E298 } \\
\text { students returning } \\
\text { fall } 2010\end{array}$} & \multicolumn{2}{|c|}{$\begin{array}{l}\text { E298 students } \\
\text { who passed the } \\
\text { course returning } \\
\text { fall } 2010\end{array}$} & \multicolumn{2}{|c|}{$\begin{array}{c}\text { Non-E298 } \\
\text { students returnin } \\
\text { g fall } 2010\end{array}$} & \multicolumn{2}{|c|}{$\begin{array}{c}\text { Other } \\
\text { comparison } \\
\text { group returning } \\
\text { fall } 2010\end{array}$} \\
\hline & Pct $\mathbf{N}$ & $\mathbf{N}$ & Pct $\mathbf{N}$ & $\mathbf{N}$ & Pct $\mathbf{N}$ & $\mathbf{N}$ & Pct $\mathbf{N}$ & $\mathbf{N}$ \\
\hline Initial cohort $\mathbf{N}$ & & 31 & & 30 & & 138 & & 87 \\
\hline $\begin{array}{l}\text { Not returning to } \\
\text { University }\end{array}$ & $6.5 \%$ & 2 & $6.7 \%$ & 2 & $4.4 \%$ & 6 & $8.1 \%$ & 7 \\
\hline $\begin{array}{l}\text { Returning to } \\
\text { University }\end{array}$ & $80.7 \%$ & 25 & $83.3 \%$ & 25 & $66.7 \%$ & 92 & $79.3 \%$ & 69 \\
\hline $\begin{array}{l}\text { Not eligible to } \\
\text { return to } \\
\text { University } *\end{array}$ & $12.9 \%$ & 4 & $10 \%$ & 3 & $29.0 \%$ & 40 & $12.6 \%$ & 11 \\
\hline $\begin{array}{l}\text { Returning to } \\
\text { college other than } \\
\text { COE }\end{array}$ & $0 \%$ & 0 & $0 \%$ & 0 & $2.2 \%$ & $\begin{array}{l}2 \text { out } \\
\text { of } 92\end{array}$ & $1.4 \%$ & $\begin{array}{c}\text { 1out of } \\
69\end{array}$ \\
\hline
\end{tabular}

*Not eligible to return - this category includes student who cannot return for academic and financial reasons (suspended, withdrawn, canceled, financial holds, etc). 
Chi-squared statistical procedures were used to compare the retention figures of these groups. For the 2008 cohort, there was no statistical difference in enrollment patterns, after one year, between students who participated in E298 and those who chose not to (but were eligible for the E298 course). In contrast, the other comparison group (students with a fall 2008 GPA between 2.0 and 2.3), were more likely to re-enroll in fall 2009. By fall 2010, the retention rate of the 2008 E298 group had dropped significantly below that of the non-E298 and the comparison group, although when only the students who passed E298 are considered, there is no significant difference in re-enrollment patterns. So, students who did not pass E298 were less likely to reenroll in the fall of their second year.

For the 2009 cohort, however, the students who did not take E298 were significantly less likely to re-enroll in the fall of 2010, as compared to the other comparison group and those who did take E298. The data will continue to be monitored in subsequent years.

Retention analysis is compounded by the variety of factors that make students non-eligible to return. These are not only academic factors, and so for a fuller analysis, non-academic factors would need to be controlled for.

Further analysis will continue to be conducted on retention, withdrawal and suspension rates. Also, students who remain will continue to be tracked throughout their undergraduate experience.

\section{(4) Evaluation of the impact of the course on subsequent learning:}

Students who were still enrolled at the University from both cohorts were surveyed at the end of fall 2010. The purpose was to identify ways in which the course had impacted their subsequent academic progress. Although the response rate was very low, with only 9 students completing the survey, the results reveal important themes. In future, we will consider surveying students early in the semester after they complete the course, so that it is still fresh in their memories. Questions were analyzed by theme, and the number of students indicating each theme is shown in brackets.

Responses from students to a question about the most helpful aspects of the course included (a) improved planning skills (7) and study habits (3), (b) improved time management and organizational skills (3), (c) recognizing they had a problem and developing a plan to address the situation (2), (d) accepting that a change of major to another degree was alright (2), (e) the opportunity to get personal assistance from an advisor (2), and learning to seek help (1).

In response to the most important things learned, students cited learning coping skills and stress management (4), time management and planning when assignments are due (3), learning to keep track of grades, building confidence, and improving study habits.

In responding to the question, 'How prepared or not prepared were you for your future university studies, as a result of taking $E$ 298?', all students indicated that they were better prepared the next semester. These quotations indicate how the course impacted subsequent academic success. 
"I was able to use the skills I learned in E298 to help me with my next semester at X University and still use a lot of them today in everyday life."

"Much more prepared, my GPA left the 1.7 range and after this semester it will be above a 3.0!"

"I felt very prepared. E298 gave me the opportunity to change the direction I was going and it was a good change."

"I was prepared enough to look at the semester and assignments in a proactive and organized fashion."

In response to a question asking them to describe their study habits since taking the course, all students indicated that their study habits had improved, shifting from the tendency to cram and study at the last minute, towards studying more consistently and well in advance. They also indicated that they review material more regularly and prepare for assignments before the due date, including doing homework assignments not for a grade. Some students (3) admitted that they still needed to further improve their study habits, but this at least indicates an awareness of a potential weakness.

Overall, quotations such as the ones below highlight the value placed on the course by students.

"It is a great course and really helped me cope with one of my worst times academically ever. I believe that other University students may experience a similar happening and will find a course like E298 useful for dealing with their first academic failure."

"Primarily it served as both a wake-up call and a life boat because it was a chance to step back and look at where I had been, where I was, and where I was going. It was very helpful to talk to different people and network with other students and administrators."

\section{Conclusion}

This paper has described a unique collaboration on the campus of a large research-extensive university. What brought these partners together was an opportunity to pilot a new course aimed at under-performing first-year students. The intervention course was piloted in spring 2009 and 2010 with a total of 99 engineering students and preliminary assessment results show some gains in grades and positive student attitudes, but variable differences in retention of students the following fall semester. A third pilot is being conducted in spring 2011, building on the lessons learned from the previous two cohorts.

Based on the successes and feedback on the course to date, the College of Engineering is requiring all students who fail the Intro to Engineering and Problem Solving course (the firstsemester engineering design course) to be enrolled in E298 this spring. In addition, we are exploring making the course mandatory for engineering students with freshmen fall grades less than 2.0. It is envisioned that this course, and the results, will be shared with the broader 
academic community with an eye toward increasing retention and graduation metrics and student success at the University.

\section{Bibliography}

1. Pan. W. (2009-2010). A multilevel approach to assessing the interaction effects on college student retention. Journal of College Student Retention, 11(2), 287-301.

2. Suresh, R. (2006-2007). The relationship between barrier courses and persistence in engineering. Journal of College Student Retention, 8(2), 215-239.

3. Friedman, B. A. \& Mandel, R. G. (2009-2010). The prediction of college student academic performance and retention: Application of expectancy and goal setting theories. Journal of College Student Retention, 11(2), 227246.

4. Moller-Wong, C. \& Eide, A. (1997). Engineering Student Retention Study," Journal of Engineering Education, 86(1), 7-15.

5. Levin, M.E., \& Levin, J.R. (1991). A Critical Examination of Academic Retention Programs for At-Risk Minority College Students. Journal of College Student Development, 32(4), 323-234.

6. Tinto, V. (1994). Leaving College: Rethinking the Causes and Cures of Student Retention. Chicago: Il, University Of Chicago Press.

7. Tinto, V. (2007). Research and Practice of Student Retention: What Next? Journal of College Student Retention: Research, Theory \& Practice, 8(1), 1-19.

8. Giaquinto, R. A. (2010). Instructional Issues and Retention of First-Year Students. Journal of College Student Retention: Research, Theory \& Practice, 11(2), 267-285

9. Felder, R., Felder, G.N, \& Diets, E. J. (1998). A longitudinal study of engineering student performance and retention V: Comparisons with traditionally taught students. Journal of Engineering Education, 87(4), 469-480.

10. Besterfield-Sacre, M., Atman, C. J., \& Shuman, L.J. (1997). Characteristics of Freshman Engineering Students: Models for Determining Student Attrition in Engineering. Journal of Engineering Education, 86(2), 139-149.

11. Hewitt, N.M. \& Seymour, E. (1991). A Long, Discouraging Climb. ASEE Prism, February 1991, 24-28.

12. Seymour, E. \& Hewitt, N.M. (1994). Talking About Leaving-Factors Contributing to High Attrition Rates among Science, Mathematics and Engineering Undergraduate Majors, Final Report to the Alfred P. Sloan Foundation on an Ethnographic Inquiry at Seven Institutions, Bureau of Sociological Research, University of Colorado: Boulder.

13. Astin, A.W. (1993). What Matters in College: Four Critical Years Revisited, San Francisco: Jossey-Bass.

14. Tobias, S., (1990). They're not Dumb, They're Different: Stalking the Second Tier. Tucson, AZ: Research Corporation.

15. Cross, K.P. (1993). On College Teaching. Journal of Engineering Education, 82(1), 9-14.

16. Caison, A.L. (2005). Determinants of systemic retention: Implications for improving retention practice in higher education. Journal of College Student Retention, 6(4), 425-441.

17. Downing, S. (2006). On Course: Strategies For Creating Success In College And In Life. Boston, MA: Wadworth.

18. Ting, S. (2001). Predicting academic success of first-year engineering students from standardized test scores and psychosocial variables. International Journal of Engineering Education, 17(1), 75-80.

19. Ting, S. (2008). Structured groups for non-traditional college students: Non-cognitive assessment and strategies. University Press of America: Lanham, MD.

20. Midgley, C., et al. (2000). Manual for the Patterns of Adaptive Learning Scales. Ann Arbor: University of Mitchigan.

21. Cohen, S., Karmarck, T., \& Mermelstein, R. (1983). A global measure of perceived stress. Journal of Health and Social Behaviors, 24, 385-396. 